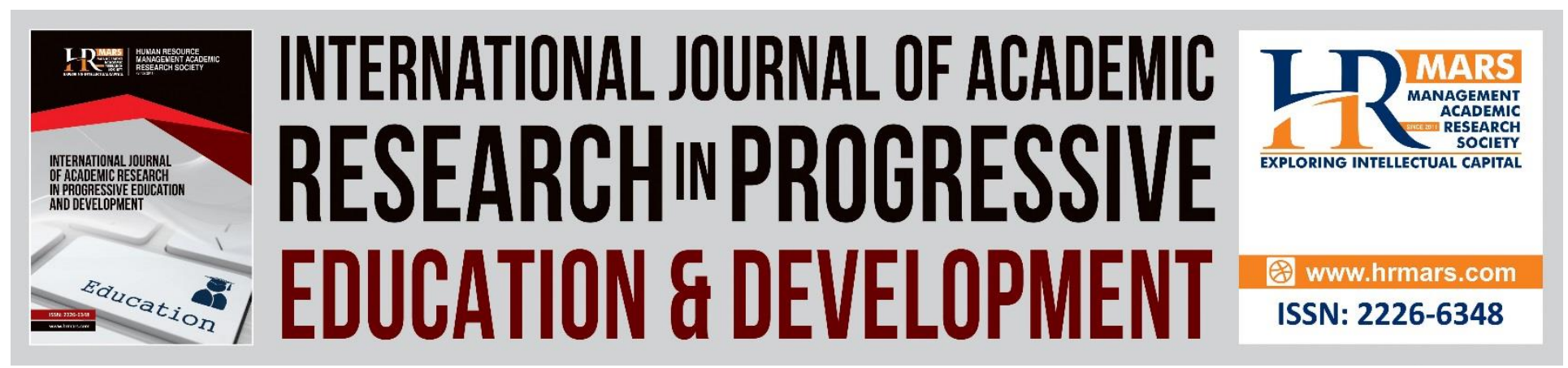

\title{
Improving English Grammar Achievement through Educational Games among Eleventh Grade Students in East Jerusalem
}

Jarrah Mohammad Al-Jarrah, Oraib Tamimi Waari, Rania Hassan Talafhah, Tamer Mohammad Al-Jarrah

To Link this Article: http://dx.doi.org/10.6007/IJARPED/v8-i1/5529 DOI: $10.6007 /$ IJARPED/v8-i1/5529

Received: 18 Dec 2018, Revised: 16 Jan 2019, Accepted: 06 Feb 2019

Published Online: 14 March 2019

In-Text Citation: (Al-Jarrah, Waari, Talafhah, \& Al-Jarrah, 2019)

To Cite this Article: Al-Jarrah, J. M., Waari, O. T., Talafhah, R. H., \& Al-Jarrah, T. M. (2019). Improving English Grammar Achievement through Educational Games among Eleventh Grade Students in East Jerusalem. International Journal of Academic Research in Progressive Education and Development, 8(1), 75-86.

Copyright: (C) 2019 The Author(s)

Published by Human Resource Management Academic Research Society (www.hrmars.com)

This article is published under the Creative Commons Attribution (CC BY 4.0) license. Anyone may reproduce, distribute, translate and create derivative works of this article (for both commercial and non-commercial purposes), subject to full attribution to the original publication and authors. The full terms of this license may be seen

at: http://creativecommons.org/licences/by/4.0/legalcode

Vol. 8, No. 1, 2019, Pg. 75 - 86

http://hrmars.com/index.php/pages/detail/IJARPED

JOURNAL HOMEPAGE

Full Terms \& Conditions of access and use can be found at http://hrmars.com/index.php/pages/detail/publication-ethics 


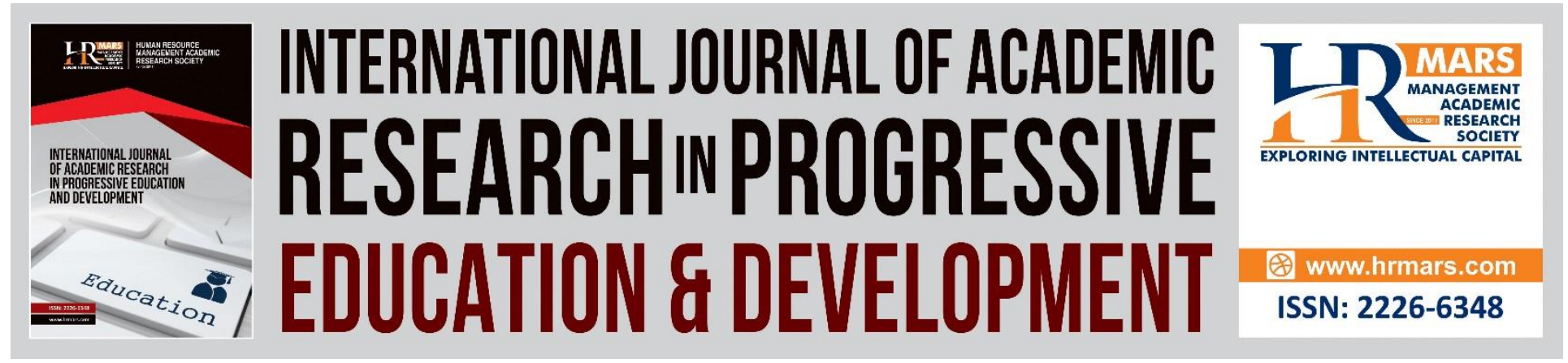

\title{
Improving English Grammar Achievement through Educational Games among Eleventh Grade Students in East Jerusalem
}

\author{
Jarrah Mohammad Al-Jarrah ${ }^{1}$ Oraib Tamimi Waari² \\ Rania Hassan Talafhah ${ }^{3}$ Tamer Mohammad Al-Jarrah ${ }^{4}$ \\ ${ }^{1}$ Assistant Professor of TEFL, Department of Educational Studies, Faculty of Islamic Studies, \\ Islamic University of Minnesota, USA \\ Email: almazarmaa@gmail.com \\ ${ }^{2}$ Teacher of English, Almamonya School, East Jerusalem, Palestine \\ Email: Oraibw177@hotmail.com \\ ${ }^{3}$ Assistant Professor of TEFL, Department of Curriculum and Instruction, Faculty of Education, \\ Yarmouk University, Jordan \\ Email: rania.talafhah@yu.edu.jo \\ ${ }^{4}$ Department of Language and Communication, Universiti Malaysia Terengganu, 21300 Kuala \\ Nerus, Terengganu, Malaysia \\ Email: tameressay@gmail.com
}

\begin{abstract}
This study has investigated the use of educational games to improve English grammar achievement among eleventh grade students at a high school for girls in East Jerusalem. It was conducted during the second term of the 2016-2017 school year. The researchers adopted an experimental approach, with a total of 62 students divided equally into an experimental group and a control group, which both completed pre- and post-tests. The experimental group was taught grammar using educational games for two months, while the control group was taught using traditional methods. The results revealed no significant difference at $\alpha=0.05$ between groups on the pre-test, while the post-test revealed a significant difference between the achievement of the experimental group $(M=77.6 \%)$ and control group $(M=68.7 \%)$. Based on these findings, the study recommends applying educational games in English grammar instruction and other language skills.
\end{abstract}

Keywords: Educational Games, Achievement, English Grammar, East Jerusalem 
International Journal of Academic Research in Progressive Education and Development Vol. 8, No. 1, 2019, E-ISSN: $2226-6348$ @ 2019 HRMARS

\section{INTRODUCTION}

Improving English Grammar Achievement through Educational Games among Eleventh Grade Students in East Jerusalem Teachers and teaching methods are key factors in the performance and well-being of any school. Student learning can be enhanced by improving instructional practices and methods. This study shows that one effective way to improve achievement in English grammar is to use games and warm-up activities within a well-defined cohesive structure.

Various empirical studies have proposed a connection between mobile learning and second language learning in the areas of writing (Silver \& Repa, 1993), speaking (Peterson, 1990), listening comprehension (Grezel \& Sciarone, 1994), grammar (Swann, 1992), and vocabulary (Kang, 1995). Mobile learning and English as a second language (ESL) instruction are associated because mobile learning makes ESL material more accessible to learners. Furthermore, mobile learning offers a greater opportunity to participate in daily instructional activities (Meskill \& Mossop, 2000). When ESL teachers work with students at different levels of English-language ability, mobile learning offers more tasks and materials that support their individual learning needs.

Teaching effectiveness is generally measured by student outcomes, which are influenced, among other things, by the teachers' performance and the strategies they employ in the classroom. However, students who speak their native language most of the day, especially at school, often find themselves tongue-tied in English classes, as shifting between languages requires mental adjustments. To use an analogy from the world of sports, just as athletes need to warm up their muscles before they can perform at their peak, English teachers can help students accomplish their ESL goals by beginning their classes with simple warm-up activities (Kay, 1995). Such activities allow students to easily flow into English and prepare them for complex topics of study.

According to Ozdamli and Uzunboylu (2015), technology does not always enhance the teaching and learning process because some teachers only use technology to support their traditional practices or select applications that support teacher-centered instruction. Dewitt called this practice "technology-enhanced traditionalism" (as cited in Miller \& Cinnamon, 2013, p. 114). Understanding the nature of mobile learning and selecting appropriate educational apps is thus important for the successful use of mobile devices in the classroom (Fayed \& Ziden, 2014; Kim \& Kwon, 2012). According to Lee and Cherner (2015), educational apps should support selfdirectedness, learner-centeredness, creativity, problem solving, and higher-order thinking skills.

These and other studies have shown that a change is needed in the way educators think about the use of games in English classrooms. This can be achieved through adopting and modifying new strategies and methods. Students need to be exposed to a less stressful learning environment that encourages them to be enthusiastic about learning and look for ways to acquire English skills through a wider variety of methods.

\section{Problem of the Study}

Language teachers tend to use traditional teaching methods, such as introducing a new idea, giving rules deductively, or explaining the lesson directly. However, students often feel bored by traditional methods of teaching grammar and fail to follow each lesson. Because of a poor foundation in the basics, their sentences often lack coherence and cohesion. The present study sought to determine whether educational games could be effective in improving students' 
achievement in grammar. The researchers believed this method could help students learn more effectively, especially because they would be actively involved in the learning process. Cárdenas (2001) emphasized that "students learn best when they can address knowledge in ways that they trust. They will learn best through doing, rather than reflecting" (p. 18).

\section{Significance of the Study}

This study could benefit those involved in language education, especially teachers and students. Teachers could implement educational games that encourage students to study in a competitive and enjoyable atmosphere. In addition, it could serve as a guideline for teachers and help them realize the importance of using games in gaining students' attention and keeping them engaged. Games would benefit students by allowing them to learn while having fun and thus be less likely to worry about errors and grades. Moreover, games give students more opportunities to learn and use grammatical rules and increase their speaking skills.

\section{Literature Review}

Studies on educational games, grammar, the effectiveness of new techniques in English grammar instruction, and education in East Jerusalem are reviewed below.

\section{Educational Games}

According to Deesri (2002), educational games can be used as more than icebreakers or to kill time. On the contrary, they are "an activity with rules, a goal and an element of fun" ( $p$. 15). He defined games as a form of play governed by rules and intended to be enjoyable while still having a clear educational goal. Moreover, they encourage the learner to use the language in the course of the game (Hadfield, 1990).

Games involve many elements, including rules, competition, relaxation, and learning. Some of these characteristics according to Caillois are listed below:

- Fun: the activity is simply fun

- Separate: it has a time and place limitation

- Uncertain: the outcome of the activity is unforeseeable

- Non-productive: participation is not productive

- Governed by rules: the activity has rules

- Fictitious: it is accompanied by the awareness of a different reality (Pequeno \& Béziau, 2011, p. 126)

The focus of games in class is thus to help students learn while having fun. However, they require a well-structured lesson with clear rules explained by the teacher. Demonstrations can help students understand the game and follow the rules.

Advantages of games. Games have many advantages, but this study focused on the ones most relevant to language learning. Games are highly motivating because they are interesting and challenging (Cárdenas, 2001). Activities in a game encourage all students to move around and activate their mental capacities, thus motivating them to learn. Furthermore, students who are shy often participate in playful activities, forgetting their normal shyness and fear. Games also employ meaningful and useful language in practical contexts. They can thus be used to practice all language skills, capturing students' attention and encouraging their participation. At 
the same time, they increase students' desire to learn more, which transforms the class into a more exciting and challenging environment.

Games promote learner interaction and cooperation because players want to score points and win (Cárdenas, 2001; Schultz \& Fisher, 1988). As a result, they are motivated to participate in the activities in groups or pairs. This context makes them more willing to ask questions, communicate, discuss, and think more creatively about how to use English.

Games also help improve language acquisition (Avedon \& Sutton-Smith, 1971; Schultz \& Fisher, 1988). Due to the motivation and interaction encouraged by games, students can acquire skills and absorb lesson content more enthusiastically than when learning through other methods. While playing, students realize they must use the language creatively if they want others to understand them (Schultz \& Fisher, 1988).

Finally, games can increase learner achievement in terms of test scores, communication ability, vocabulary, and other language skills. According to Riedel (2008), the needs of today's students call for "unconventional teaching strategies to be put into practice in the classroom. And when schools use the games, the student benefits speak for themselves - a greater desire to learn and higher test scores" (p. 20).

Classification of games. According to Lee, games have been classified into nine categories:

- Structured games that provide an experience of the use of particular patterns of syntax in communication

- Vocabulary games in which the learners' attention is focused mainly on words

- Spelling games

- Pronunciation games

- Number games

- Listen-and-do games

- [Writing games]

- Miming and role play

- Discussion games (as cited in Pham, 2007, p. 15)

In this study, researchers used structured games, listen-and-do games, and number and card games based on the students' level of knowledge and the purpose of the content.

Deciding which games to use. When choosing which games to employ, teachers should take into consideration many factors, such as students' level, characteristics, age, and motivation. Another important factor is timing when to use the game to achieve the best results. In addition, games should be fun and serve an educational purpose. Rinvolucri (1990) used games in any of the following three stages as part of grammar instruction:

1. diagnostically before presenting a given structure area to find out how much knowledge of the area [learners already have];

2. after a grammar presentation to see how much the group [has] grasped;

3. as revision of a grammar area. (p. 3)

Like Rinvolucri, this study viewed such games as "a central part of the students' learning process" rather than as a reward or merely for fun (p. 3). 


\section{Defining Grammar}

Grammar can be defined many different ways depending on how it is perceived and used. Grammar can refer to books that contain descriptions of the structure of a language or to the knowledge that a native speaker has of his or her language and to the descriptions of that knowledge (Richards \& Theodore, 2001). It can also be used to refer to a set of rules developed to control certain aspects of the usage of native speakers. In addition, it can refer to a set of rules typically taught in school about "appropriate usage" and about writing. In terms of selfexpression, Crystal (2004) defined grammar as follows:

Grammar is the structural foundation of our ability to express ourselves. The more we are aware of how it works, the more we can monitor the meaning and effectiveness of the way others and we use language. It can help foster precision, detect ambiguity, and exploit the richness of expression available in English. And it can help everyone-not only teachers of English, but also teachers of anything, for all teaching is ultimately a matter of getting to grips with meaning. ( $p$. 26) Batston conceived of grammar as "a set of categories and forms which helps us to see language as structured and systematic...or a source which language users exploit as they navigate their way through discourse" (as cited in Bouras, 2006, p. 22). According to this definition, grammar is not a set of rules that students can master easily. They need to practice the language regularly, and teachers should use many approaches to present and explain it.

How to help students with grammar. Grammar can help students with the form, meaning, and use of language, as explained below (Richards \& Theodore, 2001; Larsen-Freeman, 2000).

\section{Teaching form}

Grammatical forms are the correct ways for arranging word order and changing word endings. Teachers do not always need to explain grammar rules to students. They can often work these rules out for themselves. The teacher, however, should help the students to discover and deduct by giving them various exercises and tasks.

\section{Teaching meaning}

Teachers should always introduce a new grammar structure in a meaningful context. This context should make the meaning of the new structure clear and show how it is used in real life. This mental image/comprehension is generated by the grammar or vocabulary. Students connect the grammar structure with the meaning. For example, the past tense signals events in the past, the past perfect signals earlier actions/events in a narrative. Once the teacher has presented the structure, he will be able to talk about the meaning too.

\section{Practicing and using the language}

Practice activities help students remember the new language and become more accurate and fluent in using it. In planning practice activities for the lesson, teachers should create a balance between activities that improve accuracy getting the grammatical form right and fluency communicating a message with ease.

\section{Previous Studies on Teaching English Grammar through Games}

Numerous studies have examined the importance of using educational games in the learning process. Several found that games not only filled free time or amused students but rather were designed to capture their attention, encourage them to learn through enjoyable 
activities, and involve them actively in improving their language skills. Zdybiewska (1994) and AlJarrah et al. (2019) stated that "games help the teacher to create contexts in which the language is useful and meaningful" (p. 14). She explained that games can be interesting even to students who typically seem uninterested and who find second language learning boring.

However, few studies have examined the use of games in grammar instruction. Nguyen (2005) carried out one such study in Vietnam with 100 students and 10 teachers. The study suggested ways to present and practice grammatical rules. In the results, Nguyen emphasized that "games are [a] 'vital part' of a teacher's equipment because they provide not only practice but also an amusing and challenging [divergence] from other classroom activities" (p. 60).

Luong (2009) and Al-Jarrah, Talafhah, and Al-Jarrah, (2019) studied the application of games in grammar review lessons for sixth graders. The study surveyed eight teachers and 225 students from three high schools and included an experimental project with 82 students during three months. The results showed a dramatic improvement in students' grammatical knowledge, demonstrated in both written test scores and oral performance.

Hamzah and Dourado (2010) had similar goals, methods, and procedures to the present study. They examined the effects of integrating games into grammar instruction, noting students and teachers' responses to this change. The sample included 56 students from two classes in Malaysia. One class formed the experimental group, while the other was the control group. Data were collected via pre- and post-tests on grammar, semi-structured interviews with the English teachers, and observations of participants' reactions to the grammar games. Their study concluded the following:

1. Games were particularly useful in grammar learning because they provided a mechanism that gave students an incentive to go on practicing a structure beyond the point where they would normally tire of repeating it.

2. The games also presented the students with an authentic environment to learn and practice these tenses.

3. Teachers agreed that games played an important role in the teaching and learning process.

In a study on using games to teach tenth grade students grammar, Luu and Nguyen (2012) found games helpful in easing difficulties and making the teaching and learning experience more exciting. Students considered grammar lessons delivered by teachers who simply followed tasks from the textbook and did not create any activities to be boring and hard to internalize. According to Luu and Nguyen, these educators did not meet students' needs for more interesting and effective grammar classes.

Yolageldili and Arikan (2011) conducted a study in Turkey to explore the effectiveness of using games in teaching grammar to young learners according to the viewpoints of Turkish EFL teachers in primary schools. The researchers collected data from 15 English teachers using a questionnaire. The study suggested that while teachers accepted the effectiveness of using games in grammar teaching, they did not use games as frequently as expected in their classrooms.

The above studies all showed difficulties in learning grammar and suggested using games to create a more relaxing, motivating atmosphere for most learners. However, their pedagogical implications only concerned games carried out in traditional ways in which teachers use handouts and pictures without the aid of technology. Thus far, no attention has been paid to using games 
in electronic lessons to motivate and immerse learners in grammar lessons. In addition, previous studies have failed to emphasize the necessity of carefully choosing games suitable for the content of the lesson and students' language and grade level.

\section{Methodology}

A quasi-experiment is one where the treatment variable is manipulated but the groups are not equated prior to manipulation of the independent variable. This quasi-experimental study examined grammar achievement among female high school students in a control group and experimental group. Both groups were given pre- and post-tests, while only the experimental group participated in five grammar games. The outcomes of the tests and games were then analyzed.

\section{Paradigm and Design}

The aim of this study was to investigate the effect of using educational games on improving English grammar achievement among eleventh grade students at a high school for girls in East Jerusalem. Using qualitative paradigm helped the researchers to collect numerical data that was turned to useful statistics and used to get straight answers for research questions.

Although qualitative paradigm does not allow for in depth information, it allows for generating results from small samples to larger population particularly with representative samples.

Although the researchers preferred to use true - experimental design which allows to randomly assigning each participant to experimental and control group, and as a result minimizing the differences between groups. Unfortunately, the school system in Jerusalem does not allow for changing the formed groups in sections. As a result, the researchers used the quasi -experimental design and used two intact group of $11^{\text {th }}$ grade students ( section $A$ and $B$ )

\section{Research Questions}

This study sought to answer the following research questions:

1. Does using educational games to teach eleventh grade students in East Jerusalem improve achievement in grammar?

2. Are there any significant differences between the experimental and control groups in terms of grammar achievement on the pre- and post-tests?

\section{Hypotheses}

The following hypotheses were proposed:

1. There are no significant differences between the experimental and control groups in terms of grammar achievement as measured by the pre-test (at $\alpha=0.05$ ).

2. There are significant differences between the experimental and control groups in terms of grammar achievement as measured by the post-test (at $\alpha=0.05$ ).

\section{Population and Sample}

The population of the study consisted of 1,200 students attending an all-girls' public high school in East Jerusalem. In addition, the school employed 100 female teachers. The sample consisted of 62 eleventh grade students divided equally into two heterogeneous classes. The same teacher taught both classes. One class was used as an experimental group, which was taught using games, while the second was a control group, which was taught using traditional 
methods, including dictating rules and giving examples on the board that were to be written in students' notebooks. The main objective was to monitor whether there was any improvement in the experimental group's learning outcomes.

\section{Procedures}

This study took place at the abovementioned high school during the second term of the 2016-2017 school year from February 24, 2017 to April 29, 2017. Quasi-experimental methods were used to determine whether there was any improvement in grammar outcomes after using games. In the first stage, both classes were given a pre-test on the simple past and past continuous to examine their current ability.

Games were used in every exercise with the experimental group, whereas the control group was taught only using traditional methods, which included implementing a rule after an explanation was provided by the teacher, followed by worksheets. After the end of the treatment period, both groups took post-tests. These results were later analyzed and compared.

\section{Data Analysis}

After collecting the data, student responses were analyzed through SPSS Means and standard deviations were calculated to investigate the effect of using educational games on grammar performance. A $t$-test was used to highlight any differences.

\section{Findings}

\section{Hypothesis 1: Pre-Test Results}

Hypothesis 1 posited that there would be no significant differences between the experimental and control groups in terms of grammar achievement as measured by the pre-test (at $\alpha=0.05$ ). The researchers used a $t$-test to determine if there were any such differences between groups (see Table 1).

Table 1

Pre-Test Results

\begin{tabular}{lllllll}
\hline Group & $N$ & $M$ & $S D$ & $d f$ & $t$-test & Sig \\
\hline Control & 31 & 69.8 & 15.6 & 60 & -0.383 & 0.703 \\
Experimental & 31 & 71.2 & 13.4 & & & \\
\hline
\end{tabular}

The results showed no significant differences in terms of grammar achievement between the experimental and control groups, thus confirming the first hypothesis.

\section{Hypothesis 2: Post-Test Results}

Hypothesis 2 posited that there would be significant differences between the experimental and control groups in terms of grammar achievement as measured by the post-test (at $\alpha=0.05$ ). Once again, the researchers used a $t$-test to determine if there were any such differences between groups. 
Table 2

Post-Test Results

\begin{tabular}{lllllll}
\hline Group & $N$ & $M$ & $S D$ & $d f$ & $t$-test & Sig \\
\hline Control & 31 & 68.7 & 15.6 & 60 & -2.631 & 0.011 \\
Experimental & 31 & 77.6 & 10.2 & & & \\
\hline
\end{tabular}

The experimental group showed significantly higher grammar achievement $(M=77.6)$ than the control group $(M=68.7)$, confirming the second hypothesis. These results answered the research questions of the study and suggested that using educational games in the process of teaching grammar could strongly improve learning outcomes.

\section{Discussion and Conclusion}

The results of this study demonstrated that educational games could help students learn English grammar more effectively, which agreed with the findings of Hamzah and Dourado (2010) and Yolageldili and Arikan (2011). Furthermore, educational games played a critical role in the teaching and learning process as they provided mechanisms that gave students an incentive to practice their knowledge in an interesting and enjoyable way by creating competition while avoiding the repetition common in traditional methods. The results thus agreed with Zdybiewska's (1994) assertation that "Games help the teacher to create contexts in which language is useful and meaningful" (p. 64), even among students who are typically uninterested in second language learning.

Furthermore, educational games helped create a more engaging, encouraging learning atmosphere and reduced difficulties in teaching and learning grammar, making it easier for students to learn from their classroom experiences. Games helped students acquire necessary language skills in a more naturalistic context, during which teachers could suggest solutions to problems as they arose. These results were in line with those of Luu and Nguyen (2012).

Finally, such games encouraged greater classroom interaction and promoted enthusiasm among learners. These results agreed with Riedel (2008), who showed the advantages of games in improving learner achievement. In contrast to traditional activities, games offer peer interaction that makes it easier for learners to engage actively in the learning process. 
International Journal of Academic Research in Progressive Education and Development

Vol. 8, No. 1, 2019, E-ISSN: 2226-6348 @ 2019 HRMARS

\section{References}

Avedon, E. M., \& Sutton-Smith, B. (1971). The study of games. London, UK: John Wiley \& Sons.

Al-Jarrah, J. M., Talafhah, R. H., \& Al-Jarrah, T. M. (2019). social networking sites and English language learning: Jordanian EFL learners 'practices and experiences. European Journal of English Language Teaching.

Al-Jarrah, T. M., Mansor, N., Talafhah, R. H., \& Al-Jarrah, J. M. (2019). The application of metacognition, cognitivism, and constructivism in teaching writing skills. European Journal of Foreign Language Teaching.

Bouras, M. M. (2006). A form oriented study of the acquisition of tense and aspect by Algerian adult learners' of English (Doctoral dissertation). Retrieved from https://bu.umc.edu.dz/theses/anglais/BOU974.pdf

Crystal, D. (2004). A twenty-first century grammar bridge. The Secondary English Magazine, 7(5), 24-26.

Deesri, A. (2002). Games in the ESL and EFL class. The Internet TESL Journal, 8(9). Retrieved from http://iteslj.org/Techniques/Deesri-Games.html

Fayed, I., \& Ziden, A. A. (2014). Designing and developing learning apps for ESL learners. In Proceedings of the Second International Conference on Education and Language (pp. 106115). Lampung, Indonesia: Bandar Lampung University.

Grezel, J. E. D., \& Sciarone, A. G. (1994). Computer testing of listening comprehension. Computers \& Education, 23(1), 125-132.

Hadfield, J. (1990). A collection of games and activities for low to mid-intermediate students of English. Walton-on-Thames, UK: Nelson.

Hamzah, M. H., \& Dourado, J. E. (2010). Using grammar in teaching grammar: A case study in SMK Damai Jaya. Retrieved from http://eprints.utm.my/10214/2/ Juliana_Emilia_Dourado.pdf

Kang, S. H. (1995). The effects of a context-embedded approach to second-language vocabulary learning. System, 23(1), 43-55.

Kay, C. (1995). The role of warming up activities in adolescent students' involvement during the English class. Issues in Teachers' Professional Development, 10(1), 9-26.

Kim, H., \& Kwon, Y. (2012). Exploring smartphone applications for effective mobile-assisted language learning. Multimedia-Assisted Language Learning, 15(1), 31-57.

Larsen-Freeman, D. (2000). Techniques and principles in language teaching. Oxford, UK: Oxford University Press.

Lee, C-Y., \& Cherner, T. S. (2015). A comprehensive evaluation rubric for assessing instructional apps. Journal of Information Technology Education: Research, 14, 21-53.

Luong, B. H. (2009). The application of games in grammar review lessons for sixth graders (Unpublished master's thesis). Vietnam National University, Ho Chi Minh City, Vietnam.

Luu, T. T., \& Nguyen, T. M. (2012). Teaching English through games. Studies in Literature and Language, 1(7), 61-75.

Meskill, C., \& Mossop, J. (2000). Technologies use with ESL learners in New York State: Preliminary report. Journal of Educational Computing Research, 22(3), 265-284.

Nguyen, L. H. (2005). How to teach grammar communicatively (Unpublished master's thesis). Vietnam National University, Ho Chi Minh City, Vietnam. 
Ozdamli, F., \& Uzunboylu, H. (2015). M-learning adequacy and perceptions of students and teachers in secondary schools. British Journal of Educational Technology, 46(1), 159-172.

Pequeno, T., \& Béziau, J.-Y. (2011). Rules of the game. In J.-Y. Beziau \& M. E. Coniglio (Eds), Logic without frontiers (pp. 131-144). London, UK: College Publication.

Peterson, M. (1990). An evaluation of VOXBOX: A computer-based voice-interactive language learning system for teaching English as a second language (Unpublished doctoral dissertation). United States International University, San Diego, California.

Pham, T. H. (2007). The effects of games on optional English classes in Ben Tre primary school (Unpublished master's thesis). Vietnam National University, Ho Chi Minh City, Vietnam.

Richards, J., \& Theodore, S. R. (2001). Approaches and methods in language teaching: A description and analysis. Cambridge, UK: Cambridge University Press.

Riedel, C. (2008). Web 2.0: Helping reinvent education. Retrieved from https://thejournal.com/articles/2008/01/25/web-20-helping-reinvent-education.aspx

Rinvolucri, M. (1990). Grammar games: Cognitive, affective and drama activities for EFL students. Cambridge, UK: Cambridge University Press.

Schultz, M., \& Fisher, A. (1988). Interacting in the language classroom: Games for all reasons. New York, NY: Addison-Wesley Publishing Group.

Silver, N. W., \& Repa, J. T. (1993). The effect of word processing on the quality of writing and selfesteem of secondary school English-as-second-language students: Writing without censure. Journal of Educational Computing Research, 9(2), 265-283.

Swann, P. (1992). Computer assisted language learning for English as a foreign language. Computers \& Education, 19(3), 251-266.

Yolageldili, G., \& Arikan, A. (2011). Effectiveness of using games in teaching grammar to young learners. Elementary Education Online, 10(1), 219-229.

Zdybiewska, M. (1994). One-hundred language games. Warsaw, Poland: WSiP. 